\title{
Re-envisioning Caribbean Costa Rica
}

\section{Chinese-West Indian Interaction in Limón during the Late Nineteenth and Early Twentieth Centuries}

\author{
Benjamín N. Narváez | ORCID: 0000-0003-4093-6930 \\ University of Minnesota, Morris, MN USA \\ bnarvaez@morris.umn.edu
}

\begin{abstract}
While West Indians constituted a much larger immigrant group in the port of Limón, Costa Rica and its environs, Chinese also migrated there during the late nineteenth and early twentieth centuries. In hopes of maintaining their culture and in response to the prejudice they faced, both groups formed their own tightknit transnational subcommunities. Nevertheless, they also interacted with each other. These interactions ranged from tension and conflict on the one hand, to routine, peaceful interaction and even collaboration on the other. In particular, class differences and the marginalization these groups experienced combined to produce this complex relationship. Tension and conflict often emerged due to both sides hoping to move up the social ladder and because of the economic power that many Chinese held as shopkeepers and lenders. Nevertheless, as groups experiencing social marginalization and living in proximity to each other, they could develop neutral or positive social and economic relationships.
\end{abstract}

\section{Keywords}

Chinese - Limón - West Indians - immigration - race - class - Costa Rica

On November 28, 1897, Buenaventura Durán and her common-law husband Marcos Días witnessed a befuddling, horrific crime at the very moment they hoped to relax and enjoy each other's company. Días, a Colombian immigrant farmer, was walking his Bolivian immigrant wife home from her job as a domestic servant in Matina, Costa Rica. Along the way, they decided to enter a Chinese establishment for a ginger ale. After receiving their drinks, two Jamaican men 
entered the store and began conversing in English with one of the Chinese owners, Ghin S. Lung. Durán and Días could not understand their words, which made what they subsequently witnessed all the more strange. Lung handed over a knife to one of the men, who then stabbed him. With Lung dying on the floor, the murderer put the knife down and then left with his partner. ${ }^{1}$ What exactly had Durán and Días witnessed?

This was an extreme and confusing event, but it also spoke in various ways to daily life along Costa Rica's Caribbean coast during the late nineteenth and early twentieth centuries. As scholars have shown, Limón province, especially the port city of Limón and its environs, radically transformed with the arrival of the railroad and banana plantations. Established in 1854 , the port became a hub of international trade and migration. By the beginning of the twentieth century, the United Fruit Company was dominant, but the boom created economic openings for individual farmers, storekeepers, and others. Thus, the demand for railroad and banana workers, as well as other economic opportunities, encouraged Costa Ricans, other Latin Americans, and West Indians to migrate to the port and its environs. In fact, as many as 50,00o West Indians migrated, at least temporarily, to Limón from 1870-1930. While West Indians faced greater Costa Rican prejudice than Spanish American migrants, both groups experienced exploitation and both found ways to make Limón their home and contribute to the region's social and economic landscape. ${ }^{2}$

Few would question this characterization of Limón. Nevertheless, what Durán and Días witnessed suggests that this traditional picture remains incomplete. Although smaller in number, the Chinese also migrated to Limón, with roughly 1500 entering Costa Rica between 1855 and 1930. ${ }^{3}$ Until 1873, most arrived as indentured laborers and worked in agriculture or on the Atlantic railroad. Although Costa Rican interest in Chinese labor diminished by the

1 Archivo Nacional de Costa Rica (hereafter ANCR), Juzgado del Crimen de Limón (hereafter JCL), ooo668, "Causa criminal: homicidio de Shin J. Lung" (1912).

2 Bourgois 1989; Chomsky 1996; Harpelle 20o1; Meléndez \& Duncan 1972; P. Palmer 1993; Purcell 1993; Putnam 2002. I have calculated 50,00o West Indian migrants based on Harpelle (2001:13-7, 194n40). Putnam (2002:35) indicates over 10,00o Spanish Americans migrated to Limón before 1930.

3 I have calculated this figure by combining information from Soto Quirós (2009:3-5) and Costa Rican census data from 1927 (https://ccp.ucr.ac.cr/bvp/censos/1927/, accessed April 1, 2020) and placing it within the context of poor government record keeping, Chinese diasporic movement, and illegal immigration. The 1883 census recorded 219 Chinese, 65 of whom resided in Limón (https://ccp.ucr.ac.cr/bvp/censos/1883/, accessed April 1, 2020). Those numbers dropped in 1892 to 175 and 28, respectively (https://ccp.ucr.ac.cr/bvp/censos/1892/, accessed April 1, 2020). However, in 1927 they rose to 790 and 246, respectively. 
mid-187os, Chinese merchants began making Costa Rica home and they would come to characterize Chinese immigration moving forward. By the end of the nineteenth century, the Chinese lived throughout the country, laying the groundwork for enduring communities, particularly in the provinces of Limón, Puntarenas, and Guanacaste. Historians generally have ignored the Chinese in Limón or have viewed them as tangential to Limón's story and the history of Chinese migration to the Americas. A few have begun to consider their experience and that of the Chinese in Costa Rica more generally, addressing labor and commerce, Sinophobia, cultural retention, and community formation. ${ }^{4}$ Nevertheless, these efforts remain incomplete, with Limón's Chinese still being peripheral to scholars' understandings of the history of the port and of the Chinese diaspora.

Within the larger topic of Chinese migration to Limón, scholars have paid even less attention to the question of interaction between Chinese and West Indians, both of whom constituted marginalized groups. Of course, their experiences differed in important ways. Chinese immigration was much smaller than that of West Indians. ${ }^{5}$ Moreover, the Chinese faced an immigration ban from 1897 to 1943. Even if some Costa Ricans wanted to ban Black immigration during the same period, Blacks were not banned until 1942-well after the banana boom and the high point of West Indian immigration (Harpelle 2001:69-73, 139-43). The Chinese faced stricter scrutiny much earlier, as Costa Rican prejudice and hemispheric Sinophobia led to Chinese exclusion by the end of the nineteenth century. Those already there could stay and leave and return, but no new Chinese could enter. Costa Rica had no exempt classes, such as merchants and students-a significant difference from Chinese exclusion in the United States. The Costa Rican government also soon enacted a registry and passport system to monitor the colonia china (Chinese community). Banning Chinese immigration never succeeded fully, but it harmed the community and made maintaining transnational family and economic ties harder. ${ }^{6}$ West Indians, in contrast, more freely entered, left, and re-entered Limón (Putnam 2002). Nevertheless, despite exclusion, Limón's colonia china generally was more prosperous than the West Indian population, which made the Chi-

4 Acón 2016; Chen Mok 2013; Cohen 2008; Fonseca Herrera 2014; Huesman 1991; León Azofeifa 1987; Loría Chaves \& Rodríguez Chaves 2001; Soto Quirós 2009.

5 The 1927 census recorded 246 Chinese and 18,003 Black Antilleans in Limón out of a total population of 32,278 .

6 On Chinese exclusion in Costa Rica, see Soto Quirós 20og. On Chinese exclusion in the United States and general hemispheric Sinophobia, see Delgado 2012, Lee 2003, López 2013, McKeown 2008, and Young 2014. 
nese visible despite their small numbers. West Indians typically labored for exploitative foreign capital or had a more precarious economic independence than the Chinese who tended to be shopkeepers, merchants, businessmen, or work for their countrymen. ${ }^{7}$

Notwithstanding the differences in experience, both groups lived in proximity to each other and confronted Costa Rican hostility. This reality raises questions about their interaction. How frequently and in what ways did they interact with each other? Did they develop positive relationships or were their interactions fraught with tension and conflict? Despite the significance of both groups to Limón, scholars have not seriously considered these questions. Alonso Rodríguez Chaves and Marlene Loría Chaves suggest that Chinese-West Indian interaction "was always good" (Soto Quirós 2009:9), while Lara Putnam's work (2002) implies the opposite was the norm. Neither, however, closely interrogates the subject. Moisés León Azofeifa (1987) suggests a more complex relationship, but he does not fully address the question. Thus, as Ronald Soto Quirós (2009:9) observes, "it remains to be studied what [the] relations were between Chinese immigrants and other nationalities." By carefully examining Costa Rican archival records, including criminal cases, civil cases, and newspapers, a clearer picture of the relationship between these two groups emerges.

While these records, including the opening story, indeed reveal tension and conflict, they also suggest regular peaceful interaction and moments of collaboration. This complex relationship resulted from the marginalization these groups experienced, their class differences, their overlapping transnational connections, and, at times, gender dynamics. In hopes of maintaining their culture and in response to the prejudice they faced, both groups formed tightknit subcommunities for protection and advancement. When they did interact, tension and conflict often emerged due to both sides hoping to move up the social ladder, as well as because of the economic power that many Chinese held as shopkeepers and lenders. A transnational component to these class- and racebased tensions also existed. Both communities maintained strong ties to their conationals residing in the Greater Caribbean, especially Jamaica and Panama. Sinophobia existed in these other sites too, with Chinese once again tending to be shopkeepers and Black West Indians tending to be laborers, peasants, and farmers. Thus, similar tension and conflict emerged between these groups in these other places, and this had the power to influence these interactions in Limón. Gender imbalances, patriarchal norms, misogyny, and challenges to

7 Chomsky 1996; Fonseca Herrera 2014; Harpelle 2001; León Azofeifa 1987; Purcell 1993; Putnam 2002; Soto Quirós 2009. 
them could also intersect with racial and class tensions to produce discord. Nevertheless, much of Chinese-West Indian interaction, whether in Limón or elsewhere in the Greater Caribbean, was "neutral" and routine. Moreover, as groups living next to each other who maintained overlapping transnational connections and experienced social marginalization, they could find positive social and economic interaction mutually advantageous. Thus, shared social spaces, intergroup employment and business dealings, collaboration, and close personal relationships were well within the norm as well.

This multifaceted relationship existed during Limón's frontier era (1870s80 ), continued during the boom (189os-1920s), and persisted through the decline (late 1920s-4Os). However, tension appears to have been most pronounced during the middle period. No longer an open frontier society, the two groups clashed more during the boom because of the formation of strong subcommunities, increased Sinophobia, and a continuing general absence of Chinese women that amplified the possibility of interracial sexual encounters and unions - a form of bridging the gap that also created conflict. Discord did not vanish during Limón's decline. Nevertheless, tension softened as both groups embraced integration more and interracial unions became less frequent once more Chinese women arrived.

In examining Chinese-West Indian interaction in Limón, this article contributes to the questioning of Costa Rica's myth of exceptionalism, while deepening our understanding of the Chinese diaspora in the Americas. The myth posits that Costa Rica's modern stability and democratic tradition grew out of a history of yeoman farming and White racial homogeneity that prevented class conflict and encouraged an egalitarian and democratic ethos. Scholars, however, have increasingly questioned this vision of the past by highlighting inequality, class conflict, antidemocratic politics, and the experiences of West Indians and other groups. They also have shown how liberal elites during the late nineteenth and early twentieth centuries and later liberacionistas cultivated this myth to paper over inequalities and social tensions, create national unity, and legitimize their power. ${ }^{8}$ Drawing attention to the Chinese and their interactions with West Indians further challenges Costa Rica's myth of Whiteness and an egalitarian past. This study also contributes to the effort to uncover Chinese and Asian contributions to Latin America and the Caribbean. Following Evelyn Hu-DeHart (1980, 1989, 2002), historians of the region have increasingly focused on Chinese labor and merchant migration; Chinese economic

8 Chomsky 1996; Gudmundson 1986; Harpelle 2001; Kordick 2019; Lohse 2014; Meléndez \& Duncan 1972; S. Palmer 199o, 1996; Putnam 2002. 
contributions; Sinophobia and exclusion; Chinese social integration and struggles for inclusion; and efforts to form community, preserve culture, and maintain transnational ties. ${ }^{9}$ Costa Rica was part of this Chinese diasporic world and the Chinese experience there overlapped in various ways with the experiences of Chinese elsewhere. Even more recently, scholars have begun exploring the intersection of Afro-Latin American/Caribbean and Asian experiences in order to rethink the connections, tensions, and cooperation among marginalized groups, as well as how their interactions helped shape their societies. ${ }^{10}$ This study contributes to this reevaluation of the region's past and present, as it moves away from frameworks that privilege White-Black or White-Indigenous dichotomies for conceptualizing Latin America and the Caribbean, and instead emphasizes the importance of an "Afro-Asian" dynamic as crucial for understanding the region's development.

An obvious immigrant response to a hostile world was to form a subcommunity. As historians have shown, West Indians shared the same spaces and regularly turned to each other for support, economic advancement, to socialize, and to preserve culture and identity. They also maintained strong transnational ties to their homeland and other parts of the circum-Caribbean by migrating back and forth, sustaining family ties, and forging economic connections. Tension and ethnic differentiation among West Indians in Limón existed, but as English speakers and British subjects who shared a general culture while living in a linguistically and culturally different place, maintaining strong group ties made sense. ${ }^{11}$ The same could be said for Limón's small Chinese community. Scholars have shown how Chinese migrants to the Americas forged strong communal bonds with robust transnational ties. ${ }^{12}$ The few studies on the Chinese in Costa Rica indicate this too. ${ }^{13}$ However, a careful review of Costa Rican criminal and

9 Chang 2017; Delgado 2012; González 2017; Jung 2006; López 2013; McKeown 2001, 2008; Romero 2010; Schiavone Camacho 2012; Siu 2005; Young 2014; Yun 2008.

10 See Yun 2008; the special 2008 issue of the Afro-Hispanic Review (27:1), guest-edited by Evelyn Hu-DeHart and Kathleen López; and Ossa \& Lee-DiStefano 2019.

11 Chomsky 1996; Harpelle 20o1; Meléndez \& Duncan 1972; P. Palmer 1993; Putnam 2002.

12 Delgado 2012; González 2017; Hsu 2000; Lee 2003; López 2013; McKeown 2001; Romero 2010; Schiavone Camacho 2012; Siu 2005; Young 2014.

13 Chen Mok 2013; León Azofeifa 1987; Loría Chaves \& Rodríguez Chaves 20o1; Soto Quiros 2009 . 
civil cases, immigration records, and newspapers provides a deeper picture of how the Chinese created a tightknit transnational subcommunity in Limón.

Chinese cooperated economically. Chinese businesses were often joint ventures, including with family and nonfamily members. ${ }^{14}$ Chinese immigrants also relied on each other as lenders and acquired goods for their businesses on credit from each other. ${ }^{15}$ These business relations were also transnational. Some investment came from overseas Chinese and some in Limón maintained business interests in China or other parts of the Americas, frequently traveling between locations. José William serves as an example. He arrived in Limón in the 188 os and quickly established a business. In 1902, he went to China to see family, returning two years later. In 1905, he traveled to China again to see family and deal with business interests connected to his two stores in Limón. ${ }^{16}$ Likewise, in 1910, Henry Lyen left Charles Lea Fong Tsong in charge of their grocery and liquor store in Limón for 14 months - Lyen had invested 2, ooo colones in the business and Fong Tsong 3,00o colones-while he traveled to Colón, Panama to attend to other business interests. ${ }^{17}$

14 ANCR, Juzgado Civil de Limón (hereafter JCivL), ooo866, "Expediente de información: Francisco Yee Ham solicita probar que León Jon o Hong fue conocido como Shan $\mathrm{O} \mathrm{Hi}$, Shan Wo Hi y José León" (1908); Protocolos Notariales (hereafter PN), oo1632, $\mathrm{P}_{5}, \mathrm{~F}_{37}, \mathrm{n}_{3} 6$, "Constitución mercantil: Chinese Trading Company Limited" (1908) and oo1632, P5, F39, n36, "Constitución mercantil: Chinese Trading Company Limited" (1908); JCL, ooo668, "Causa criminal: homicidio de Shin J. Lung” (1912); Juzgado Penal de Limón (hereafter JPL), Oo2520, "Causa criminal: hurto, Tomás Acón Castro en perjuicio de Yee Wo" (1928); Ministerio de Gobernación (hereafter MG), oo3178, "Solicitud de residencia: Ka Chong" (1913); MG, oo7966, "Sumaria sobre la introducción clandestino de José Chong y Tomás Kío" (1930).

15 ANCR, Protocolo Lara y Chamorro (hereafter PLC), T3, P1, F41, "Testamento: Juan Allen" (1880); Juzgado Civil y del Crimen de Limón (hereafter JCCL), oooo12, "Deuda: José León contra Shan Wo Hi" (1900); JCCL 0oo188, "Prejuicio de posiciones: Concurso de Francisco José contra Chon Leyo" (1900); JCCL, 000561, "Embargo preventivo: Concurso de Francisco José contra Loi Kee" (1900); JCCL, ooo569, "Embargo preventivo: Esau Lyen contra Sam Lee" (1903); JCCL, ooo577, "Embargo preventivo:José Manuel Delgado contra Sin Foo Chin" (1904); Alcaldía Unica de Limón (hereafter AUL), oo2232, "Embargo preventivo: Concurso de Isaac Charles Lean contra Wo Chong" (1901); AUL, oo213o, "Embargo preventivo: Lindo Bros. contra Sing Wo" (1903); Juzgado de lo Contencioso Administrativo (hereafter JCA), ooog12, "Causa criminal: Contra Guillermo Castro por depósito de aguardiente clandestino" (1903); JCivL, oo1721, "Expediente de solicitud: Juan José León solicita que se declare en estado de quiebra a Wong Hop Lee" (1915); Remesa 1563, ooo383, "Juicio ejecutivo: Carlos Ching Molina contra la sucesión de Juan José León" (1933).

16 ANCR, Secretaría de Policía (hereafter SP), oo1688, "Solicitud para inscribirse en el registro chino: José William" (1905).

17 ANCR, JCL, OO380, "Sumaria para averiguar si Lea Charles Fong Tsong estafó a Henry Lyen" (1912). 
Chinese immigrants relied on one another economically in additional ways. Sometimes they rented space from their countrymen for their businesses. ${ }^{18}$ They also regularly hired family and compatriots. ${ }^{19}$ Moreover, some merchants had started out as the employees of other Chinese. ${ }^{20}$ As a fourteen-year-old in 1910, Manuel León Yee began working in a store owned by Joaquín León Yee in Germania. Fifteen years later, Manuel took over the store when Joaquín returned to China. More than a decade later, he was still operating the establishment. ${ }^{21}$ As Manuel León Yee's story and those of others indicate, Chinese immigrants often sold property or transferred their businesses to each other, with some returning to China or heading elsewhere in the Americas after these transactions. ${ }^{22}$

Members of Limón's colonia china looked to each other to defend the community's interests and take political action as well. In 1911, Chinese in Limón and Puntarenas jointly petitioned the national congress to lift the immigration ban and let them bring their families over from China. ${ }^{23}$ Likewise, Chinese merchants in 1908 and 1917 collectively asked the national government to stop the efforts of some Costa Ricans to eliminate them from the liquor business. ${ }^{24}$ Leaders of Limón's colonia china also wrote open letters defending the commu-

18 ANCR, Remesa 1447, Oooo15, "Causa criminal: Tentativo de incendio en perjuicio de Juan José León Yee" (1919); Remesa 1563, ooo383, "Juicio ejecutivo: Carlos Ching Molina contra la sucesión de Juan José León" (1933).

19 ANCR, AUL, OO3441, “Injurias: Juan José León contra Ema Chabeau y Rosa Núñez” (1909); JCL, Ooo373, "Causa criminal: Estafa, Willam Samuel contra Juan Francisco" (1912); JCivL, oo1749, "Expediente de información, registro de chinos: Wing Chong Fo" (1913); JCivL, oo1754, "Expediente de información, registro de chinos: Willy Yong" (1913); JCivL, oo176o, "Expediente de información, registro de chinos: Win Lung" (1913); JCivL, oo1835, "Expediente de información, registro de chinos: José Afó" (1913); Ministerio de Gobernación y Policía, Gobernación de Limón (hereafter MGPGL), 058504, "Empadronamiento de chinos" (1935).

20 ANCR, JPL, OO2520, "Causa criminal: Hurto, Yee Wo contra Tomás Acón Castro" (1928); MG, oo7966, "Sumaria sobre la introducción clandestino de José Chong y Tomás Kío” (1930).

21 ANCR, Ministerio de Relaciones Exteriores y Culto (hereafter MREC), 024865, "Naturalización: Manuel León Yee” (1936).

22 ANCR, PLC, T3, P5, F19, "Compraventa:Juan Ennis y Hing Hing” (1882); JCA, ooog12, "Causa criminal: Contra Guillermo Castro por depósito de aguardiente clandestino” (1903); PN, oo1632, $\mathrm{P}_{5}, \mathrm{~F}_{7} 6 \mathrm{v}, \mathrm{n}_{78}$, "Venta de establecimiento: José Gil y José Chang" (1908); MrEc, 024865, "Naturalización: Manuel León Yee" (1936).

23 ANCR, Asamblea Legislativa (hereafter AL), oo9578, "Solicitud de varios chinos de Puntarenas y Limón contra el decreto de 20 de Mayo de 1897” (1911).

24 ANCR, AL, OO1O264, "Solicitud de varios chinos de Limón contra la modificación del Artículo 16" (19o8); MG, 045532, "Queja de varios chinos de Limón contra el Agente Principal de Policía" (1917). 
nity's reputation. ${ }^{25}$ Chinese in Costa Rica and throughout the Americas also participated in Chinese national politics as the Qing dynasty collapsed and China entered a turbulent political period. ${ }^{26}$ In May 1911, as China's republican revolution neared, Chinese in Limón and Puntarenas honored Tam Pui Shum, a Chinese imperial diplomat visiting Mexico and Central America (Soto Quirós 2009:24-29). While Costa Rica's Chinese celebrated this Qing diplomat, many overseas Chinese supported Sun Yat-sen's republican nationalist movement. In fact, republican support existed in Costa Rica too and became evident after the revolution. On January 1, 1919, leading merchants in Limón and Puntarenas united and formed a branch of the diasporic Republican League in support of Sun Yat-sen. ${ }^{27}$ In 1930, Limón's Chinese were still collectively celebrating the anniversary of Republican China. ${ }^{28}$

Chinese immigrants supported each other in lower profile ways as well. Those with immigration issues and legal troubles turned to their compatriots. ${ }^{29}$ As historians of Chinese migration to the Americas have shown, covert transnational collective action also helped with circumventing exclusion laws. ${ }^{30}$ Illegal immigration was central to the community's growth in Costa Rica, and the government and general public worried about it. ${ }^{31}$ Chinese on the Atlantic and

25 La Información (San José), December 20, 1914.

26 González 2017:24; Hsu 200o:150-54; Kuhn 2008:239-81; López 2013:177-85; Young 2014: 248-70.

27 El Heraldo (Puntarenas), January 3, 1919.

28 Limón Searchlight (Limón), October 25, 1930.

29 ANCR, Sala Segunda de Apelaciones (hereafter sSA), o00540, "Consulta del fallo en la causa criminal contra Sam Lee por incendio" (1903); JCivL, ooo884, "Expediente de información: Guillermo Castro para probar su buena conducta y que es casado en China” (1906); SP, oo1688, "Solicitud para inscribirse en el registro chino: José William" (1905); MG, o03178, "Solicitud de residencia: Ka Chong" (1913); MG, 034867, "Datos sobre la naturalización de chinos" (1917); MG, 039781, "Correspondencia entre el Ministerio de Gobernación y Agencias de Policía sobre chinos en el país" (1920); MG, 033802, "Juan José Gil Cunyick otorga fianza para José Sing” (1921); MG, oo7966, "Sumaria sobre la introducción clandestino de José Chong y Tomás Kío" (1930); Remesa 1447, oooo49, "Expediente de detención arbitraria: Chang Luís contra Amador Escalante Rogelio" (1922); JPL, oo2520, "Causa criminal: Hurto, Yee Wo contra Tomás Acón Castro" (1928).

$30 \quad$ Delgado 2012; Lee 2003; López 2013; Romero 2010; Young 2014.

31 ANCR, MG, O25783, "Acta de sesiones del municipio de Cañas: Pronunciamiento contra los chinos" (1901); Municipalidad de Puntarenas, o12784, "Correspondencia entre el gobernador de Puntarenas y el administrador de aduana de Puntarenas sobre la entrada ilegal de chinos" (1911); SP, oo6o32, "Carta del 6 de julio del gobernador de Puntarenas al Presidente Jiménez sobre el ingreso de chinos al país" (1911); MG, 039781, "Correspondencia entre el Ministerio de Gobernación y Agencias de Policía sobre chinos en el país” (1920); MG, o08043, "Notas sobre inmigración china" (1924); Congreso, o13838, "Proyecto del diputado Gerardo Zúñiga Montúfar sobre el cumplimiento de la ley de inmigración 
Pacific coasts used clandestine landings and border crossings, forged documents, and used the identity of others to get into the country (Soto Quirós 2009:14-24). Chinese cooperation inside and outside of Costa Rica made this system work. Prospective immigrants needed assistance getting documents, arranging transportation, and gaining information that could help with answering immigration officials' questions. If they made it into the country, they needed their compatriots to quickly whisk them away and find them housing and work.

The case of Tomás Kío and José Chong, who attempted to enter Costa Rica via Limón in 1930, offers a glimpse of how this worked. On November 20, the Ulúa arrived with four Chinese men carrying Costa Rican passports and Costa Rican naturalization papers. Based on these documents, officials let them into the country. Soon after, however, other officials became suspicious of the documents, believing the men were not who they claimed to be. The authorities detained Tomás Kío and José Chong, but the other two disappeared. Investigators discovered that archived naturalization records existed for all four, but the passports they had used were fraudulent. Moreover, Kío and Chong spoke no Spanish and their answers to investigators' questions indicated they were actually other people. The authorities eventually learned the men had been caught before trying to enter the country illegally. This time they had obtained fake documents in Colón, Panama with the help of Chinese from Limón and Puntarenas, and members of Limón's colonia china were expecting them. ${ }^{32}$

Based on these levels of cooperation, it should come as little surprise that Limón's Chinese established their own social world that was closely linked to the larger diaspora. Chinese immigrants often lived together, lived in the same neighborhoods, and rented housing to each other. ${ }^{33}$ They also found ways to socialize and maintain culture. They regularly played games, gambled, and held

china" (1924); MGPGL, 058504, "Empadronamiento de chinos" (1935). El Noticiero (San José), September 13 and 24, 1911; El Grito del Pueblo (Puntarenas), July 5, 1909; El Correo de la Costa (Puntarenas), February 13, 1914; El Pacífico (Puntarenas), January 6, 1917; El Tiempo (Limón), March 11, April 25, May 3, 20, 30, September 8, 11, 14, 30, 1911. Letter No. 2050a, Lieutenant Colonel Fred T. Cruse to the U.S. Department of War, November 26, 1930, in Conditions in Costa Rica. N.p., Mar. 3, 1920. World Scholar: Latin America \& the Caribbean. worldscholar.tu.galegroup.com/tinyurl/5aAZXX, accessed November 28, 2017. ANCR, MG, oo7966, "Sumaria sobre la introducción clandestino de José Chong y Tomás Kío" (1930).

33 ANCR, JCL, OOO380, "Sumaria para averiguar si Lea Charles Fong Tsong estafó a Henry Lyen" (1912); JPL, OO2520, "Causa criminal: Hurto, Yee Wo contra Tomás Acón Castro" (1928); Remesa 1563, ooo383, "Juicio ejecutivo: Carlos Ching Molina contra la sucesión de Juan José León" (1933). 
festivities together. ${ }^{34}$ Chinese immigrants formed associations as well, which created space for socializing and preserving culture, while potentially serving as mutual aid and lending organizations for members. Juan José Gil Cunyick led the effort to form a Chinese Freemason club in Limón in 1918, and two years later Limón's Chinese had established a branch of the Chee Kung Tong Association. ${ }^{35}$ Associational life also transcended national borders. The Chee Kung Tong operated throughout the Americas, and Limón's members wanted delegates from the Panamanian chapter in Bocas del Toro at their association's inauguration. ${ }^{36}$ Limón's Chinese generally came from the same area, Enping, which indicates close transnational social ties (Instituto Confucio 2016:8-10). Furthermore, transnational Chinese families were common, with male immigrants financially supporting and visiting wives and children back in China. ${ }^{37}$ Some also attempted to bring their immediate and extended family over from China after years of separation, especially if they had become naturalized Costa Rican citizens. ${ }^{38}$ In other cases, Chinese families had the bones of those who had died in Costa Rica exhumed and sent back to China. ${ }^{39}$ Finally, in a further sign of strong transnational bonds, Chinese had family in other parts of the Americas and traveled to China, Jamaica, Panama, and Peru for additional personal reasons. ${ }^{40}$

34 Limón Weekly News (Limón), August 15 and 29, September 26, 1903; The Times (Limón), December 17, 1910; El Tiempo, December 17, 1910.

35 ANCR, MG, 039781, "Correspondencia entre el Ministerio de Gobernación y Agencias de Policía sobre chinos en el país” (1920).

36 ANCR, MG, 039781, "Correspondencia entre el Ministerio de Gobernación y Agencias de Policía sobre chinos en el país" (1920). For the Chee Kung Tong elsewhere, see McKeown (2001:183-91), López (2013:179-80), and Young (2014:250-6o).

37 ANCR, MG PGL, 057883 (1916); MG, 034867, "Datos sobre la naturalización de chinos" (1917); MG, 039781, "Correspondencia entre el Ministerio de Gobernación y Agencias de Policía sobre chinos en el país" (1920); MGPGL, 058532, "Empadronamiento de chinos" (1934).

38 ANCR, SP, O01462, "Solicitud: Chon Leyo y Guillermo Castro piden permiso para la entrada de sus familias" (19o6); MG, o34867, "Datos sobre la naturalización de chinos" (1917); MG, 035327, "Solicitud:Juan José Gil y Chin Con piden permiso para traer sus familias de China" (1922); MG, oo7986, "Informe del gobernador de Limón sobre la entrada de los chinos Alfonso Amy, Gilberto Achón, Luís Araya y Luís Leó” (1930).

39 ANCR, MG, O02878, "Solicitud: Juan Quirós pide permiso para exhumar los restos de su hermano" (1912).

40 ANCR, JCCL, Ooo216, "Juicio de sucesión: Juan Carlos Ennis y Brown" (1895); MG, o31385, "Comunicaciones entre el gobernador de Limón y el Ministerio de Gobernación sobre un chino que pretende ser súbdito inglés" (1896); JCCL, ooo270, “Deuda: José León contra Sha Wo Hi" (1898); SP, oo1376, "Investigación oficial: entrada de San King Yong” (1901); SP, OoO251, "Solicitud de regreso: Samuel Russell por no ser chino sino inglés" (1904); SP, oo0305, "Solicitud: José Gil, entrada de su hermano" (1908); MGPGL, 057961, "Registros 
Before transitioning to a close analysis of Chinese-West Indian interaction in Limón, it is worth reflecting on Chinese transnational ties and their overlap with West Indian ones to gain a better understanding of the context in which these relationships developed. As indicated above, Limón's Chinese were particularly connected to Chinese in Panama and Jamaica. Chinese laborers and then merchants headed to these two places during the second half of the nineteenth century. By the early twentieth century, the Chinese had developed relatively large, tightknit communities in Kingston, Panama City, Bocas del Toro, and Colón. They also came to have an outsized commercial presence, especially in food retail. By 1911, Jamaica had 2,111 Chinese. Ten years later there were 3,896 and by 1943, more than 12,00o. Likewise, Panama had 3,00o Chinese in 1890 and well over 7,000 by 1913. Despite various forms of integration, Jamaican and Panamanian Chinese experienced a backlash because of their economic success, hemispheric Sinophobia, and nationalism. Panama enacted Chinese exclusion laws in 1904 and violent riots against Chinese businesses occurred in Jamaica in 1918. Despite these obstacles, the Chinese developed these communities and connected them to each other, China, Costa Rica, and elsewhere via commerce, family, communication, and travel. ${ }^{41}$

Intertwined Chinese communities in Panama, Jamaica, and Costa Rica also overlapped with the West Indian diaspora. Jamaica had a Black majority. Moreover, while Limón became a hub of West Indian migration before the 193os, Panama was an even larger one. West Indians in Costa Rica and Panama also were connected deeply to each other and to Jamaica. They constantly moved between these zones until the rise of anti-Black immigration laws in the circum-Caribbean beginning in the late 1920s. Likewise, Chinese and West Indian economic roles were similar in all three societies. Thus, Chinese and West Indians in these places found themselves interacting under similar class and gender dynamics and in Sinophobic societies that privileged Whiteness, and then they moved between locations. In fact, the complex relationship between Chinese and West Indians that was present in Limón similarly existed in Jamaica and Panama. Chinese merchants and West Indians there too developed economic relationships in which the former tended to provide goods and services and even employment for the latter. But economic power differentials and the perception of Chinese retail monopolies could create friction. Separation and confrontation occurred at the same time as routine interaction, friend-

de ingreso y pasaportes de chinos" (1912-1914); MG PGL, 058043, "Desembarque, registro y pasaportes de chinos" (1911-1915).

41 For the Chinese in Jamaica and Panama, see Siu 2005, Anshan 2004, Bouknight-Davis 2004, Hu-DeHart 2009, Robinson 2010, and Putnam 2011 and 2014. 
ship, and more. Both groups may have discouraged cross-racial sexual liaisons and unions, but they also happened — especially in Jamaica. ${ }^{42}$ Ultimately, these overlapping diasporic ties informed Chinese-West Indian interaction in Limón, especially during the boom when the West Indian community was most connected to the diaspora.

\section{$2 \quad$ Ambivalent Economic Interaction}

Although West Indians and Chinese in many respects shared Costa Rica's Caribbean coast while occupying separate worlds, they did not isolate themselves from Costa Ricans or each other. Economic conditions forced interaction. Economic relationships were not always equal and this could cause tension. More often than not, the Chinese were shopkeepers who had greater economic standing than West Indians. This is not to say that all Chinese were wealthy and all West Indians were poor. However, this general economic dynamic played a role in shaping their interaction. Specifically, it meant that West Indians often relied on Chinese businesses for goods, services, lines of credit, and more. Clearly, a general economic power dynamic existed that favored the Chinese, which could produce problems. But this economic interaction was simply a part of everyday life, one which did not have to produce resentments and could even benefit West Indians despite their generally more precarious economic position. These class dynamics and multilayered economic relationships existed during the 1870 os and 188 os but became most pronounced during the boom, as both groups' economic roles solidified.

And yet, the dual and routine nature of these economic interactions are not obvious at first glance because of the limitations of archival sources. West Indian and Chinese immigrants left limited historical records of their own, especially when it came to their interactions. Instead, most of the extant documents were recorded by Costa Ricans for whom the everyday was of little interest. West Indians and Chinese tend to appear in government records when problems arose - as accusers, victims, and perpetrators. The Costa Rican public similarly fixated on these things rather than the mundane, so newspaper records tilt this way, too. Therefore, these two groups appear together in criminal and civil records and newspaper reports, but the nature of these sources

42 For the West Indian diaspora in the Caribbean and Chinese-West Indian interaction in Jamaica and Panama, see Anshan 2004, Bouknight-Davis 2004, Hu-DeHart 2009, Putnam 2002, 2006, 2011, 2013, and 2014, and Siu 2005. 
means that tension and conflict stand out most. Nevertheless, by carefully reading them, a clearer picture emerges of daily life, including the Chinese and West Indians sharing space and interacting with each other in neutral, cooperative, and mutually beneficial ways. This is true in terms of their economic relationship and, as discussed later, their social lives.

The opening story about the murder of Ghin S. Lung represents extreme Chinese-West Indian conflict, but it also hints at everyday economic interaction. Lung and his compatriot Juan José were running an establishment in Matina that Spanish-speaking workers and West Indians regularly frequented. When the Jamaican culprits, farmer Arthur Brocks and laborer Shedrack Recid, entered the store, Marco Días and Buenaventura Durán were not the only other customers. Two other Jamaicans were purchasing goods and witnessed the attack. Moreover, Brocks and Recid were not entering Lung's business for the first time, and one of the Jamaican witnesses testified to knowing the involved parties, suggesting that this was a small world in which Chinese and West Indian immigrants regularly interacted and did business with each other.

Of course, something happened that turned a regular economic interaction between a Chinese merchant and West Indian customers into a violent encounter. That trigger appears to have been an argument over matches. Brocks and Recid had been drinking at the establishment earlier that day. After Recid grabbed a matchbox for customers and lit his pipe, a Chinese clerk accused him of trying to steal the matches. Recid denied it, but the clerk ripped the matchbox out of his hands, cutting his fingers in the process. The two men left but returned that night. Brocks immediately asked Recid, "which one of the Chinese cut you?" and then told him to cut the Chinese individual as payback. As the encounter escalated, Lung grabbed a knife and taunted Recid to take it and cut him. An inebriated Recid seized the knife, stabbing Lung in the chest. Although Brocks and Recid were arrested, they escaped from jail in December 1897 and were never found. ${ }^{43}$

Ultimately, then, this incident speaks to conflict and the daily and mundane nature of economic interactions between Chinese and West Indians. For many West Indians and others in Matina, going to this Chinese establishment was normal. There they could drink, smoke, or buy goods for their daily lives. And yet, this encounter also highlights the generally one-sided nature of this economic relationship, with the Chinese as store owners and West Indians as customers with limited options and bargaining power. This is not to suggest that Chinese businessmen were economic parasites as Sinophobes contended.

43 ANCR, JCL, ooo668 “Causa criminal: Homicidio de Shin J. Lung” (1912). 
It is simply to acknowledge that Chinese merchants filled a void that granted them some economic power and produced regular face-to-face interactions with West Indian and Spanish-speaking customers. The intimate and uneven nature of this relationship could create resentments, arguments, and even violence, as Evelyn Hu-DeHart (1980, 1982, and 2009) has made clear elsewhere. Alcohol and the argument over matches played a role in Lung's death. But the economic/class dynamic between victim and perpetrator was part of the larger context in which this violence occurred. Recid may have tried to steal matches, but the Chinese clerk's own prejudice toward a poorer West Indian customer could have encouraged him to view Recid as a thief. Recid did not have an easy life; drinking and smoking offered an escape. However, pursuing these activities meant giving money to Chinese store owners. Being called a thief and feeling fleeced could have intensified resentment toward the Chinese. In the end, Recid killed Lung, but their story speaks to the complex nature of ChineseWest Indian economic interaction.

The economic reliance and power dynamics between these two groups, as well as the tensions this produced, became clear beyond Lung and Recid's confrontation. Occasionally, West Indians sold and Chinese bought, especially property. ${ }^{44}$ But property sales could actually reflect the stronger economic position of the Chinese, since they could be buying land or buildings from struggling West Indians. Moreover, West Indians often relied on Chinese businesses for food, goods, alcohol, tobacco, and other services, such as laundry. ${ }^{45}$ Patronizing Chinese businesses did not usually elicit extreme violence, but similar frustrations could produce outbursts, with West Indian customers destroying merchandise and damaging stores. ${ }^{46}$

In a further sign of the everyday, intimate, and unequal nature of these economic interactions, West Indians regularly bought goods on credit from Chinese merchants. In 1878, Jamaican railroad worker George Moore had a debt of 32.65 pesos with Chinese merchant Juan Geddes for various provisions. West

44 ANCR, PLC, T3, P5, F21, "Venta de finca: Nathaniel Kurkindall Wallace y Juan Ennis" (1882); PLC, T3, P8, F31, "Compraventa: James Wilwood Francis y Tomás Teenga" (1883); PN, o1632, $\mathrm{P}_{5}, \mathrm{~F} 56, \mathrm{n} 54$, "Venta de establecimiento: Samuel Shaw Joyles y Ghin Sing Lee" (1908); JPL, o01527, "Sumaria para investigar un incendio en una sociedad china" (1922).

45 ANCR, AUL, OO2878, "Causa civil: Ismael Wade Morrison contra Rafael Mauryen sobre devolución de ropa” (1908); AUL, o03441, "Injurias: Juan José León contra Ema Chabeau y Rosa Núñez” (1909); JCL, ooo662, “Causa criminal: Contra Teófilo Quesada por falsedad de documento en perjuicio de José Juan” (1912); JCL, ooo93o, "Sumaria para averiguar si Sin Fot violó a Wilhemina Clarke" (1915); JCL, ooo984, "Sumaria para averiguar si José Juan robó dinamita" (1915). Also see P. Palmer 1993:92, 149-50.

$46 \quad$ El Tiempo, February 23 and March 12, 1911. 
Indian domestic Janett Rowe owed Fai Lee 30.55 colones for merchandise in $1896{ }^{47}$ Likewise, in 19o1, St. Lucian carpenter Romains Arlain had a debt of 41 colones with Hop Lee Wo for goods from his store. ${ }^{48}$ The following year, Jamaican domestics Emilia Anderson and Marie Brown and Jamaican laborer Phillip Higginson owed 22.75, 10.70, and 17.20 colones, respectively, to Chinese merchant Ghin Wo for items bought on credit. ${ }^{49}$ Relying on credit continued into the 1930 s. $^{50}$ These debts suggest West Indians and Chinese merchants interacted frequently and developed trust. But purchasing goods on credit also reflected economic power asymmetry. Many West Indians had little choice other than to contract small debts because their incomes were limited and precarious. They could not always pay their balance, which produced problems. In all of the cases highlighted above, Chinese merchants sued over these debts. Moreover, unpaid debts and efforts to collect them within a larger Costa Rican context of Sinophobia and anti-Black sentiment could feed into more general racial and class resentments. For Chinese store owners, unpaid balances could reinforce notions of West Indians as Limón's riffraff, while lawsuits could reinforce West Indian views of the Chinese as economic leaches. Either way, the intersection of race, class, and economics could drive a wedge between these communities at the same time that it brought them together.

Trust, dependence, and tension also manifested themselves when West Indians contracted larger debts with Chinese businessmen for more than consumer goods. Occasionally, Chinese merchants had debts with West Indians. ${ }^{51} \mathrm{Nev}-$ ertheless, Chinese merchants usually served as lenders. In Matina in 189o, Jamaican Marcos McKense borrowed 54.80 colones from Chinese merchant Manuel Castro, agreeing to pay it off with profits from his small banana farm. ${ }^{52}$ That same year, I.H. Soloman, who was growing bananas, coconuts, yams, and sugar cane, renegotiated a debt of 136 pesos with Manuel Castro. ${ }^{53}$ Lizie Arnold

47 ANCR, Judicial, o11o27, "Deuda: Juan Geddes contra George Moore” (1878); AUL, oo1779, "Deuda: Fai Lee contra Janett Rowe" (1896).

48 ANCR, AUL, oooo16, "Embargo preventivo: Concurso de Francisco José contra Romulis Arlains" (1901).

49 ANCR, AUL, O02647, "Deuda: Ghin Wo contra Marie Brown" (1902); oo2648, "Deuda: Ghin Wo contra Emilia Anderson" (1902); oo2649, "Deuda: Ghin Wo contra Phillip Higginson" (1903).

$5^{\circ}$ ANCR, Remesa 1240, o0o15o, "Prejuicio de posiciones: Tong Ching contra Simeón Kenty" (1934).

51 ANCR, PLC, T3, P1, F41, “Testamento:Juan Allen” (188o); AUL, oo1998, “Embargo preventivo: Samuel Daly contra Man Lee" (1903).

52 ANCR, Judicial, o146o8, "Reconocimiento de documento: Manuel Castro contra Marco McKense" (189o).

ANCR, Judicial, o146o9, “Deuda: Manuel Castro contra Marco McKense” (189o). 
in Limón owed Shin Wo over 300 colones in $1900 .{ }^{54}$ Less than a decade later, Elmos Filistory Grant had a debt of 378 colones with Chinese merchant Enrique Quesada, while Luis Genning owed Hop Wo Song 500 colones. ${ }^{55}$ By 1916, West Indian farmer John Christy Wilson and Barbadian artisan Hilary Beckles had contracted debts of 7,000 and 3,000 colones each with Juan José León Yee. ${ }^{56}$ Borrowing helped West Indians pursue farming, business opportunities, and self-employment, while providing Chinese merchants with income. But as with small consumer debts, these cases entered the historical record because Chinese lenders sued West Indian borrowers for defaulting on their loans, signaling economic interdependence and discord. And yet, in some cases, Chinese merchants and West Indians were able to renegotiate payment plans, which further showed durable relationships and trust in each other. ${ }^{57}$

Chinese merchants served additional banking functions. In some instances, West Indians deposited earnings with them, but this could produce disagreements. The routine nature of economic interactions and the tensions that ensued are evident in a 1901 case in Limón, in which Jamaican artisan William Samuel accused Juan Francisco, a Chinese merchant, of stealing his money. At the time, Francisco was operating a general store owned by another Chinese merchant. The store was located next to United Fruit offices and housing for its workers. This location was good for selling items to West Indian workers, but Francisco also held savings deposits for them. Jamaican artisans Aaron Edwards and Samuel Ferguson had deposits with Francisco, and they claimed to have witnessed William Samuel deposit $£_{13}$ in May. All three insisted they saw Francisco record the transaction in his ledger book.

But problems began in August, when Samuel wanted his money. At first Francisco claimed he had used the money in business dealings but would get it back shortly. Francisco then insisted Samuel had never deposited anything with him. By October, Samuel was pursuing legal action. When confronted with his ledger book by the district alcalde (a local chief administrative and judicial officer), Francisco insisted the deposit in Samuel's name referred to Samuel paying off a debt. The alcalde did not believe Francisco and ordered him to pay Samuel $£_{13}$. He refused and went to jail. Soon, a clear Chinese-West Indian racial divide

\footnotetext{
54 ANCR, JCCL, OOO344, "Embargo preventivo: Shin Wo contra Lizie Arnold" (1900).

55 ANCR, JCCL, ooo673, "Deuda: Enrique Quesada contra Elmos Filistory Grant" (1907); JCCL, ooo615, “Deuda: Hop Wo Song contra Luis Gening” (1908).

56 ANCR, JCivL, oo132o, “Deuda: Juan José León Yee contra John Christy Wilson” (1916); JCivL, o01323, "Deuda: Juan José León Yee contra Hilary Beckles" (1918).

57 ANCR, Judicial, ol1o27 "Deuda: Juan Geddes contra George Moore" (1878); JCCL, ooo344, "Embargo preventivo: Shin Wo contra Lizie Arnold" (1900); JCCL, oo673, "Deuda: Enrique Quesada contra Elmos Filistory Grant" (1907).
} 
came to the fore. Francisco tapped into negative stereotypes about West Indians, claiming that Edwards and Ferguson were disreputable witnesses and that the three should not be believed because Jamaicans banned together and lied to protect each other. Francisco eventually secured his release on bond but was jailed again in January 1902 for fear he would flee to Jamaica. He was rereleased after becoming ill and then disappeared, much to Samuel's chagrin. ${ }^{58}$ Ultimately, the case highlights everyday economic interaction, while revealing how these relationships could produce discord and feed stereotypes and prejudices in Costa Rican society that marginalized both groups.

A legal dispute in Swampmouth from 1902 offers further insight into daily economic interaction. That December, Mary Lawson de Malar went to the train station to buy a ticket to Limón, but the agent did not have change for her $\$ 10$ US gold coin, which prompted her to seek change at Ghin Wo's store. According to Lawson de Malar, Wo took her money and gave her half the value in colones. When she complained, the Chinese shopkeeper insisted she had given him a \$ 5 US gold coin. An angry Lawson de Malar then sued. Although several West Indian witnesses testified she had a $\$ 10$ US gold coin, the court absolved Wo since no one witnessed the exchange. ${ }^{59}$ In this case, going to the Chinese store for change seemed reasonable. In fact, in smaller communities along the Caribbean coast, a Chinese store might have been the main option. West Indians, therefore, relied on Chinese merchants for mundane economic activities like exchanging money, but these encounters could still produce discord. Here, it is unclear if Wo abused his power as a store owner interacting with a patron who had little social power or if this was a simple misunderstanding. Lawson de Malar, however, was certain he had cheated her.

Economic relationships went beyond retail and banking. Some West Indians rented accommodation from Chinese. This further reflected the economic power dynamic between the two communities, with tension and evictions occurring when payment lagged. ${ }^{60}$ The same could be said for Chinese hiring West Indians. Some worked as regular employees for Chinese businesses, while

$5^{8}$ ANCR, JCL, OOO373, “Causa criminal: estafa, Willam Samuel contra Juan Francisco" (1912).

59 ANCR, SSA, OOO805, "Sumaria para averiguar si Ghin Wo estafó a Mary Lawson de Malar" (1903).

6o ANCR, PLC, T3, P1, F41, "Testamento: Juan Allen" (1880); Judicial, o04346o, "Desahucio: Shan Who Fíe contra Henry Morgan" (1896);AUL, oo2423, "Consignación de llaves: Thomas Dalhouse y Manuel Castro" (1902); JCL, 000823, "Sumaria para averiguar si Honorio Avendaño Castillo estafó a Juan José León Yee” (1915); JCL, ooo93o, "Sumaria para averiguar si Sin Fot violó a Wilhemina Clarke" (1915); JPL, o01527, "Sumaria para investigar un incendio en una sociedad china" (1922); Remesa 1563, ooo383, "Juicio ejecutivo contra la sucesión de Juan José León" (1933). 
others served as domestics. ${ }^{61}$ Chinese individuals also hired West Indian skilled laborers. In 1902 in Moín, Ghin Wo hired Ephraim Noble to build a new house and furniture. The two already had an economic relationship since Noble had a debt of nearly 16 colones with Wo for shirts and other items. ${ }^{62}$ Likewise, in 1908 in Port Limón, Chinese shopkeeper William Shing contracted Jamaican plumber Edward Scott Hilton to put new pipes in his establishment. ${ }^{63}$ In these cases, West Indians and Chinese operated on more equal economic footing since the latter needed the former's skills, but disagreement still happened, as evidenced when these West Indian contractors sued. Noble accused Wo of not paying him in full and Wo demanded Noble pay off his debt. In the end, they worked things out. The Shing-Hilton case was uglier. Shing would not pay Hilton because he claimed Hilton had used the wrong pipes and then charged him for more expensive ones. Hilton denied this, demanded payment, and sued Shing for defamation after he called him a "damn thieving son of a bitch" and a "piece of shit." Multiple Jamaicans testified on his behalf, but Hilton dropped the case. Clearly, Chinese and West Indians relied on each other economically, which could strengthen and mar their relationship.

The 1899 story of Jamaican farmer Francis Davis and Chinese merchant Ah Pao brings these points together, highlighting the multifaceted nature of Chinese-West Indian economic relationships. In this case, the former sued the latter, but the two had a close economic and likely social relationship. Pao owned a business in Limón and employed West Indians as cart drivers and to care for his horse. At the same time, Davis was living in his home, likely renting a room. In January, Davis bought Pao's horse and cart for 239 colones. Two weeks later, however, Davis sued Pao for knowingly selling him a sick horse. Pao countered that Davis knew the good condition of the horse since he lived in his house and that Davis had mistreated the animal. As Davis's suit proceeded, Pao sued Davis for a debt of 100 colones. In the end, the court sided with Pao in the original case; the result of the countersuit is missing. ${ }^{64}$

Although conflict ultimately characterized the relationship between Ah Pao and Francis Davis, there was more to it. Pao had economic power over Davis as

61 ANCR, PCL, T3, P1, F41, "Testamento: Juan Allen" (188o); SSA, ooo540, "Consulta del fallo en la causa criminal contra Sam Lee por incendio" (1903); JCL, O00823, "Sumaria para averiguar si Honorio Avendaño Castillo estafó a Juan José León Yee” (1915); JCL, ooo93o, "Sumaria para averiguar si Sin Fot violó a Wilhemina Clarke" (1915). See also P. Palmer 1993:137.

62 ANCR, AUL, O02545, "Deuda: Ephraim Noble contra Ghin Wo" (1902).

63 ANCR, AUL, O03481, "Injurias: Edward Scott Hilton contra William Shing" (1908).

64 ANCR, AUL, ooo77o, "Causa civil: daños, Francis Davis contra Ah Pao" (1899); ool155, "Embargo: Ah Pao contra Francis Davis" (1899). 
his landlord and seller, but Pao provided Davis with a roof over his head and the opportunity to buy a horse and cart that could help him farm. Moreover, the two undoubtedly had a deeper relationship considering their shared living space. Nevertheless, once the horse became ill, friction reared its head. A clear West Indian versus Chinese dynamic emerged as Davis turned to his compatriots to testify on his behalf. Likewise, three "experts" testified, and the only one supporting Davis was Jamaican. But it was not that simple. Pao hired West Indians and some of them testified on his behalf. Ephraim Noble, the Jamaican carpenter mentioned earlier, also supported Pao. In some ways, then, West Indians and the Chinese constituted separate communities who interacted through economic exchange. These dealings did not always occur on an even playing field and they could produce resentments and conflict that reinforced notions of racial difference and prevented the two from seeing their shared marginalization in a society that privileged Whiteness. Nevertheless, both sides could benefit from these economic interactions and these encounters could help them forge deeper ties. All of this can be discerned in the example of Ah Pao and Francis Davis.

\section{Social Conflict, Cooperation, and Solidarity}

If the economic situations West Indians and Chinese found themselves in produced complex and contradictory relationships, the racism and marginalization they experienced in Costa Rican society only intensified the multifaceted nature of their social interactions. As previously suggested, economic interactions could feed into negative stereotypes of the other, or these encounters could already be colored by these prejudices. Economic-related tension could be more than economic. But racist beliefs about the other were also reinforced by more general Costa Rican racism toward both groups. Although they came from different backgrounds and hoped to maintain their cultural identities, neither wanted to be discriminated against and placed at the bottom of society. This fear encouraged internalizing negative views of the other and social distancing in hopes of rising up the social ladder. Feelings of powerlessness prompted lashing out at each other or cooperating with Costa Ricans at the other's expense. Thus, different experiences of racial discrimination encouraged friction and conflict. ${ }^{65}$ Moreover, a heavily male Chinese community led to interracial sex and unions, but these relationships and their possibility

65 Disunity is unsurprising considering West Indian banana workers, despite Costa Rican prejudice, often claimed social superiority over Spanish-speaking workers by highlighting 
could fuel discord due to notions of gender, honor, and race. These tensions were most pronounced during the boom, when both subcommunities were strongest, Sinophobia was most intense, and the social fluidity and openness of the frontier era had diminished. However, race, gender, and hierarchy could not drive a complete wedge between them. As marginalized communities who regularly interacted and shared space, as opposed to discriminated enclave communities infrequently crossing paths, the Chinese and West Indians also found cooperation and forming close relationships with each other advantageous.

Lara Putnam highlights social conflict in a defamation lawsuit Chinese merchant Juan José León Yee brought (and later dropped) in 1909 against Jamaican domestics Emma Charles and Rosa Núñez (Putnam 20o2:146-47, 156). However, it is worth revisiting this case and considering it within a larger context of Chinese-West Indian interaction, since it speaks to everyday encounters and the ways in which conflict reflected race and gender in Limón. When León filed suit, he claimed the women had insulted him in his store, calling him a "thief," "shameless," the son of a "Chinese whore," and worse. The women responded that León had hurled insults and started the argument. Their testimony indicated that shopping at León's store was not an unusual activity for them, but one day while there he berated them over politics. Republican presidential candidate Ricardo Jiménez - who would win — was visiting Limón, and León had decorated his store in republican blue. The young women, in contrast, wore red civilista-party badges. Charles claimed an irate León called her "a vagabond, crook," and insisted "that only the shameless and thieves and drunks wore civilista badges, because the civilistas were idiot sons of bitches." A later encounter fared no better. Returning another day to buy meat, the women explained they laughed at the sound of Chinese employees speaking Cantonese. In response, León asked them in English "if they liked having sex with chinos." Charles responded, "only a woman who was totally shameless could sleep with a chino, as it is well known that the Chinese are really filthy." Angered, León insulted them and then sued, claiming the ladies had damaged his reputation. ${ }^{66}$

This incident reminds us how Chinese and West Indians did not live separate lives and sheds light on how some interactions produced discord. In this case, what began as a typical marketplace encounter turned into a political

their British ties and claiming to be more cultured. Spanish-speaking laborers responded with their own beliefs about Black inferiority, see Purcell 1993:30-40 and P. Palmer 1993: $119-20$.

66 ANCR, AUL, o03441, “Injurias: Juan José León contra Ema Chabeau y Rosa Núñez” (1909). 
argument with possible racial and gender undertones coming from León (that is insults toward female civilistas that overlapped with limonense stereotypes about West Indian laziness, degeneracy, and thievery), and then into an explicitly racial and gendered conflict. León's store was a contact zone in which León seemingly had power as a store owner, but from which both could benefit. In the beginning, León felt confident on his property, berating the women for supporting the civilistas - despite Jiménez being less popular in the province (Putnam 2002:26on62). He may have been passionate about Jiménez's candidacy, but the economic dynamic in conjunction with Costa Rican patriarchy and discrimination toward West Indians needs to be factored into explaining his anger and words. León experienced Sinophobia, but he had power as a man and was engaging two women from another racially marginalized group. It is hard to imagine him yelling this way at Costa Ricans and even male West Indians.

Nevertheless, the power dynamic becomes blurred in the final encounter. Here we see both sides confident in their superiority. Chinese people speaking their language made Charles and Núñez laugh. This hinted at a sense of superiority over the Chinese, but León demonstrated his sense of power over women and West Indians when he inappropriately propositioned them. In response, Charles and Núñez tried to reclaim superiority and "remind" León of his low status by flipping gender on its head and appealing to race via the assertion that nothing was more degrading than sex with chinos. Putnam has shown this gendered racial claim was common in Limón when women and men insulted women (Putnam 2002:107, 150-52). León still believed he deserved deference from Charles and Núñez, so he yelled at them and then sued. And so, we have an ugly argument and lawsuit rooted in race, gender, and class. Both sides had internalized prejudices from the dominant society and hoped to claim a semblance of social superiority over the other, even if it did little to challenge limonense society's privileging of Whiteness.

Sex with "chinos" was not just an insult hurled by non-Chinese. This was a literal boundary that some Chinese and West Indians hoped to construct between each other. But individuals occasionally transgressed this boundary, particularly Chinese men with West Indian women, which then caused tension. Putnam highlights two cases that speak to this dynamic (Putnam 2006:122-23). In 1899, Jane Cummings, a Jamaican woman, got into an ugly public argument with a young Jamaican man over the fact that she had left her Jamaican lover for a Chinese man. In another case from 1915, a Chinese family became upset over an interracial union. Po Wo An had been dating Theresa Green, an eighteenyear-old Jamaican woman, but upon learning of her pregnancy his family pressured him to end the relationship. Nevertheless, in this case racial lines did not 
bother Theresa's mother. She pressured them to marry, which they did. Others also have noted that Limón's Chinese community often did not accept the offspring of informal Chinese-West Indian unions as Chinese (Robinson 2010:116), signaling a lack of acceptance of the other.

Chinese-West Indian tension and conflict also occurred when Costa Ricans took advantage of these vulnerable groups and wielded power over them. This was evident in 1907, when Matina's police chief Teófilo Quesada enlisted Jamaican painter George Baxter to help frame José Juan, a Chinese shopkeeper. A month after someone stole dynamite from a railroad warehouse in Pacuarito, Quesada arrested José Juan for the missing dynamite. According to Quesada, he had overheard several Jamaicans discussing how some Chinese in town had knowingly bought some of the stolen dynamite. Based on this knowledge, he asked Vicente Solís, a policeman from Estrada, to help him conduct a registry of Matina's Chinese businesses to find the dynamite. At José Juan's place they found dynamite and wicks. Once José Juan was behind bars, Quesada coaxed a signed confession from him. George Baxter served as witness and translatorJosé Juan spoke English but not Spanish. In court, Solís confirmed finding the dynamite. Baxter also explained that some Jamaicans had informed him that local Chinese had dynamite. Or so Quesada, Solís, and Baxter claimed. Pretty soon their story unraveled. José Juan insisted he had never seen the dynamite before Solís discovered it, and he told the court he had refused to sign the confession because it was not translated and he could not understand it. Under pressure, he signed in Chinese characters, but refused to sign his Spanish name "José Juan." He saw Baxter forge his signature at Quesada's behest. As the court further questioned José Juan's accusers and other witnesses, some began indicating or confessing it was a setup. Baxter admitted neither he nor José Juan knew the contents of the confession; he forged José Juan's Spanish signature because Quesada told him to do it. Some witnesses also heard Baxter boasting about planting the dynamite, to which Solís and Baxter eventually confessed. Again, Baxter insisted he was following Quesada's commands. By 1908, the court had dropped the case against José Juan and begun one against Quesada, Solís, and Baxter. ${ }^{67}$

In exploring why these men framed José Juan, it becomes even more apparent how vulnerable being Chinese or West Indian could be and how this could fuel discord. Matina's police chief Teófilo Quesada clearly led the conspiracy. José Juan claimed Quesada framed him because he would not lend him money.

67 ANCR, JCL, ooo662, "Causa criminal: Contra Teófilo Quesada por falsedad de documento en perjuicio de José Juan” (1912); ooo984, “Sumaria para averiguar si José Juan robó dinamita" (1915). 
José Juan feared that having to collect the debt would inflame the police chief. However, he could not win since the loan denial made Quesada angry. $\mathrm{He}$ bemoaned Quesada had sworn to "get revenge and he has." ${ }^{38}$ José Juan may have been a store owner, but being Chinese limited his social power. Quesada and Vicente Solís did not hesitate to use their authority against him, an action likely colored by anti-Chinese sentiment.

But this was not just a case of local authorities abusing a Chinese individual. George Baxter also participated. One witness claimed Baxter was acting out of personal animosity toward José Juan. Baxter never explained this disagreement, but testimony indicated he was poor and the bad blood could have been a reflection of their economic interactions since he and other West Indians patronized José Juan's store. Thus, when Quesada explained they could "fuck [joder]" José Juan and promised a reward, Baxter agreed. However, Baxter insisted he was following Quesada's orders, which José Juan confirmed by labeling Baxter Quesada's "puppet." ${ }^{99}$ Clearly, Quesada called the shots and seemingly directed Baxter as his puppet master, but this characterization is also misleading, since a puppet cannot think for itself and Baxter had his own reasons for participating. Still, Baxter was following orders and was in no position to refuse. Quesada was abusing his power against José Juan, what would stop him from doing the same toward Baxter, a lowly Jamaican laborer? Much like José Juan, Baxter had a precarious social standing, which encouraged acquiescence. Thus, Costa Ricans from their privileged position in society could directly influence Chinese-West Indian conflict.

Contempt, however, did not always characterize Chinese-West Indian feelings for each other. Beyond neutrality or indifference, some forged good relationships and respected the other. Although Chinese merchant Juan José León Yee was in conflict with Emma Charles and Rosa Núñez in 19o9, he had become a well-respected figure to many West Indians by the time he died in 1930. Upon his death, the West Indian Limón Searchlight praised León as a pillar of Limón's community. ${ }^{70}$ The paper reflected the perspective of West Indian elites (Harpelle 2001:72-7); poorer West Indians may not have felt the same toward León. Nonetheless, León had employed West Indians, rented housing to them, lent them money, lived in proximity to them, and had been involved

68 ANCR, JCL, OOo662, “Causa criminal: Contra Teófilo Quesada por falsedad de documento en perjuicio de José Juan” (1912).

69 ANCR, JCL, Ooo662, "Causa criminal: Contra Teófilo Quesada por falsedad de documento en perjuicio de José Juan” (1912); ooog84, “Sumaria para averiguar si José Juan robó dinamita" (1915). 
in the community. ${ }^{71}$ The paper depicted Limón's colonia china positively in other instances as well, such as highlighting Blacks, Chinese, and Costa Ricans celebrating the country's independence together or praising the Chinese for holding republican values. ${ }^{72}$

The historical record also reveals non-elite Chinese and West Indians socializing and forging close bonds. Despite forming their own subcommunities, the two frequently crossed paths. They could even live in the same neighborhoods and buildings. ${ }^{73}$ This proximity made avoiding the "other" difficult and contributed to various levels of acceptance. An investigation into the death of Chinese laborer "Saco" in 1894 provides a glimpse of this social interaction. Saco died along the train tracks near the river Pacuare. The physical evidence suggested a train had hit him, but there were no witnesses. Although he died alone, Saco had been in Siquirres interacting and socializing with local West Indians. He first went to a store and bought things from a West Indian clerk. Then he made his way to Miss Junies's to buy some cake-she was a Jamaican woman selling out of her home. He never bought the cake, but left with another Jamaican woman, Izabela Moss. The two were headed for Pacuarito and agreed to travel together. However, when they reached the river, Moss left Saco because he tried to pay her to have sex in a banana field. ${ }^{74}$ Saco's last day demonstrates the regular interaction and socializing that existed among Chinese and West Indians, especially in towns outside of Puerto Limón. In a reversal of economic roles, Saco was purchasing from West Indians. Miss Junies and another Jamaican lady, Rebecca Gayle, indicated that they knew Saco. More revealingly, Izabela Moss did not hesitate to head to Pacuarito with him. She only left when propositioned. Her willingness to travel together suggests that keeping each other company was not outside the norm.

71 Limón Searchlight, September 27, November 1, 1930. ANCR, JCL, O01551, "Reconocimiento de una cuenta: Juan José León contra la Junta de Educación de Matina” (1913); JCL, ooo823, "Sumaria para averiguar si Honorio Avendaño Castillo estafó a Juan José León Yee" (1915); JCL, o01320 (1916); JCL, o01323, "Deuda: Juan José León Yee contra Hilary Beckles" (1918); MGPGL, 058018, "Carta del 12 de setiembre del gobernador de Límón al Cónsul McMillin de los EE.UU. sobre la colonia china en Limón" (1918); Remesa 1447, oooo15, "Causa criminal: tentativo de incendio, Miguel Angel Aguilar Quirós en perjuicio de Juan José León Yee" (1919); Remesa 1563, ooo383, "Juicio ejecutivo contra la sucesión de Juan José León" (1933). See also León Azofeifa 1987:169-81.

72 Limón Searchlight, September 20 and October 25, 1930.

73 ANCR, AUL, Ooo77o, "Causa civil: daños, Francis Davis contra Ah Pao" (1899); AUL, oo2423, "Consignación de llaves: Thomas Dalhouse y Manuel Castro" (1902); Remesa 1447, 000015 , "Causa criminal: Tentativo de incendio, Manuel Angel Aguilar Quirós en perjuicio de Juan José León Yee” (1919). See also Putnam 2002:149.

ANCR, Judicial, o19183, "Sumaria para averiguar la muerte del chino Saco" (1894). 
Indeed, collaboration, friendships, and supportive relationships did occur. Some Chinese became close enough with West Indians to use them as character witnesses during immigration cases. ${ }^{75}$ Moreover, when Chinese attempted to enter the country illegally, they sometimes reached outside their community for support. This might entail bribing Costa Rican officials. ${ }^{76}$ In other instances, they cooperated with local West Indians. Some West Indians involved in these cases served as local officials, while others were ordinary residents. ${ }^{77}$ This collaboration could be transactional, but it also suggests familiarity, trust, and intimacy. Moreover, many of the Chinese entering Limón came via Jamaica or Panama, thereby making this cooperation understandable. In September 1911, officials in Limón began investigating Chinese clandestine landings in Cahuita. Witnesses claimed they saw a Chinese man secretly landing with the help of several Black men. Others accused West Indian Amos Dixon, Cahuita's judge of the peace, of enabling Chinese illegal immigration. ${ }^{78}$

Three years later, Jamaican Walter Vaughan, who worked as an official interpreter and port superintendent in Limón, faced charges of corruption, including possible connections to Chinese illegal immigration. Vaughan accused the interim governor of being corrupt and of being the one involved in immigration fraud. However, another West Indian testified that he, his associate, and Vaughan had agreed to help Chinese in Limón smuggle in their compatriots from Jamaica by providing fake passports for 100 colones each. Leaders of Limón's Chinese community denied involvement, insisting any claims implicating them did not merit credence "because those individuals are enemies of this city's colonia china, with the quality of both [testifiers] being Jamaican."79 As the Chinese noted, they often did not get along with Jamaicans. But even if Vaughan and others wanted to smear them, evidence exists of Chinese residents abetting illegal immigration. The Vaughan and Dixon cases indicate West Indians helped, too.

75 ANCR, MG, O34867, "Datos sobre la naturalización de chinos" (1917).

76 ANCR, Congreso, o13838, "Proyecto del diputado Gerardo Zúñiga Montúfar sobre el cumplimiento de la ley de inmigración china" (1924); MG, oo7966, "Sumaria sobre la introducción clandestino de José Chong y Tomás Kío" (1930). La Información, September 14, 1911. Letter No. 2020, Lieutenant Colonel Fred T. Cruse to the U.S. Department of War, August 6, 1931, in Conditions in Costa Rica. N.p., Mar. 3, 1920. World Scholar: Latin America $\&$ the Caribbean. worldscholar.tu.galegroup.com/tinyurl/5aAZXX, accessed November 28 , 2017.

77 Officials in Limón occasionally appointed West Indians to local positions of authority (P. Palmer 1993:80).

78 El Noticiero, September 13, 1911; La Información, September 13 and 14, 1911.

79 La Información, December 10, 11, 12, 13, 15, 16, 17, and 20, 1914. 
Sex, marriage, and family became another way these communities intersected. Most Chinese men in Limón who married did so with Chinese women, many of whom remained in China. However, a few married outside their group, while others formed informal unions and second families with nonChinese women. León Azofeifa suggests that legal and most common-law marriages occurred with Spanish American women, but sometimes Chinese men cohabited and formed unions with West Indian women, especially in smaller towns and rural areas (Azofeifa 1987:197-207, 336-37). Cross-racial partnering became less common after the 1940s, when more Chinese women entered the country once exclusion ended. It was also less controversial during Limón's frontier era; conflict over these relationships and the insult "sex with chinos" occurred more during the boom. Informal unions are hard to trace precisely because of their informality, but the fact that legal marriages between Chinese men and Jamaican women can be found in the historical record suggests that unofficial unions occurred.$^{80}$ Chinese-West Indian family formation needs more study, but it is clear it happened, and these partnerships could serve as bridges between both communities.

One final story speaks to the tension and ties between Chinese and West Indians. José Luís, a Chinese merchant in Cieneguita, had a good relationship with his neighbor Eloisa Walker, a West Indian woman who made a living renting rooms to West Indian men. Trusting Walker, Luís asked her in 1914 to store merchandise in her home. He worried his home's state of disrepair made him vulnerable to thieves. She agreed, but after several days of storing the items, a Jamaican man named Albert Williams stole most of them. Williams was a drifter who had arrived a month earlier from Bocas del Toro and was temporarily staying with Walker's neighbor Robert Lehman, a Jamaican brakeman who knew Williams from his past in Bocas del Toro. Seeing an easy opportunity to make money, Williams stole Luís's things. Nevertheless, various witnesses, including Lehman and the West Indian men living with Walker, testified against Williams, noting they had seen Williams possessing some of Luís's items or suddenly being flush with cash. These witnesses further asserted that Williams was a vagabond and troublemaker running from the law in Bocas del Toro. The judge ultimately sentenced Williams to nine months in prison and to repay Luís. $^{81}$

José Luís's fear of the goods being stolen proved prophetic, and a Jamaican culprit only furthers the point about these communities clashing. However,

8o ANCR, PLC, T3, P1, F41, “Testamento: Juan Allen" (1880). Also recall the cases highlighted by Putnam on pages $26-27$.

81 ANCR, JCL, oo1096, “Causa criminal: Hurto, contra Albert Williams” (1915). 
the beginning and end of the story provide a counternarrative. Luís lived next to West Indians and was more than an acquaintance of Eloisa Walker's. He knew her well enough to trust her with his possessions. Sinophobia, anti-Black prejudice, and class did not stop these two from cooperating. The fact that a number of West Indians testified against Albert Williams further suggests that intra-group solidarity at the expense of the "other" had its limits. West Indian derision of the Chinese was not strong enough in this case for Williams's compatriots to "stick together" and cover for him.

While West Indians and Chinese formed their own subcommunities in Limón, they both shaped the province's economic and social formation. The West Indian contribution, with its much larger population, is more obvious. Their labor and economic endeavors enabled the port to flourish and their large presence and transnational ties ensured Costa Rica's Caribbean coast would culturally be part of the English Caribbean in addition to being Latin American. Though few in numbers, the Chinese had an outsized impact on the region. They had significant commercial success, establishing stores and businesses that provided many of the goods and services of everyday life. Non-Chinese sometimes worked for Chinese employers. Some Chinese merchants became active in the local community. Moreover, Limón's Chinese connected Costa Rica to a larger network of overseas Chinese. Finally, both groups offered Costa Rican nationalists scapegoats for the country's troubles and served as useful "others" for those attempting to forge national unity and to construct a White national identity.

In some respects, these two groups existed separately and made their contributions to Limón independently of each other. However, they crossed paths in complex ways that reflected race, class, gender, and the influence of overlapping transnational ties. These were not always equal relationships, particularly when one considers the economic advantage Chinese merchants had over most West Indians, but these interactions could also be routine and benefit both parties. At times, Chinese and West Indians could form stronger social bonds. Although much of their interaction had a "neutral" or ambivalent character to it, clear examples of cooperative relationships, friendships, and intimacy existed. And yet, the historical record seems to highlight discord more than harmony. Intentional social separation, arguments, and violence were not abnormal. At times, separation and conflict represented gender and class differences between Chinese and West Indians, but this tension also reflected 
their own prejudices toward the other and the racism they both experienced in Costa Rica. In fact, keeping one's distance or lashing out became a way to try to claim social superiority over another marginalized group and avoid being at the bottom of society. Ultimately, West Indians and Chinese constituted distinct yet overlapping communities - for better, for worse, or somewhere in between.

While these interactions and relationships remained multifaceted throughout this period of study, there is a sense, despite the limitations of the sources, that tension and conflict peaked between the late 189os and 1920s. During this period, anti-Chinese sentiment in Costa Rica was most pronounced and their subcommunities were strongest. This was also an era in which the Chinese community remained overwhelmingly male, which encouraged cross-racial sexual relations that also heightened tension. On either end of this period, hostility may have been less pronounced, but the dynamics behind this differed. During the 1870 and 188 os, Chinese and West Indians in Limón interacted in a frontier society. Although the class dynamics that would differentiate them were beginning to form, neither faced the racism they would later. Nor was either group large enough to develop an ethnic enclave and avoid interaction. In this frontier setting, interracial sex and unions were more accepted. By the end of the 1920s, Limón looked different and these changes offer hints as to why tension and conflict may have declined. In the late 1920s and 1930s, Limón's economy faltered and Costa Rican hostility toward West Indians increased. Many West Indians left. Those who stayed increasingly embraced integration and a politics of respectability to gain acceptance. The Chinese too had been integrating and had become respected members of the community. Thus, the increasing acceptance of the Chinese and West Indian emphasis on integration and respectability encouraged a less hostile environment between the two. Moreover, once more Chinese women began arriving, interracial unions declined. This reduced a potential source of friction, but also something that could bring these communities together. Still, acceptance of the other was beginning to prevail.

\section{References}

Acón, Lai Sai, 2016. Migraciones de chinos a Costa Rica y su consecuente proceso de asimilación desde 1855. Revista Estudios 33:706-24.

Anshan, Li, 2004. Survival, Adaptation and Integration: Orgins and Evolution of the Chinese Community in Jamaica (1852-1962). In Andrew Wilson (ed.), The Chinese in the Caribbean. Princeton NJ: Markus Wiener Publishers, pp. 41-68.

Bouknight-Davis, Gail, 2004. Chinese Economic Development and Ethnic Identity For- 
mation in Jamaica. In Andrew Wilson (ed.), The Chinese in the Caribbean. Princeton NJ: Markus Wiener Publishers, pp. 69-9o.

Bourgois, Phillipe, 1989. Ethnicity at Work: Divided Labor on a Central American Banana Plantation. Baltimore MD: Johns Hopkins University Press.

Chang, Jason Oliver, 2017. Chino:Anti-Chinese Racism in Mexico, 1800-1940. Urbana: University of Illinois Press.

Chen Mok, Susan, 2013. Radiografía de una inmigración china en Puntarenas, Costa Rica. Revista Estudios 26:104-23.

Chomsky, Aviva, 1996. West Indian Workers and the United Fruit Company in Costa Rica, 1870-1940. Baton Rouge: Louisiana State University Press.

Cohen, Lucy, 2008. Emigración de chinos a Costa Rica 1872-1873. Revista Ciencias Sociales $119(1): 39-53$.

Delgado, Grace Peña, 2012. Making the Chinese Mexican: Global Migration, Localism, and Exclusion in the U.S.-Mexico Borderlands. Stanford CA: Stanford University Press.

Fonseca Herrera, Zaida M., 2014. Las migraciones chinas a Costa Rica en el siglo XIX. In Patricia Galeana (ed.), Historia comparada de las migraciones en las Américas. Mexico City: UnAM-Instituto Panamericano de Geografía e Historia, pp. 161-79.

Gónzalez, Fredy, 2017. Paisanos Chinos: Transpacific Politics among Chinese Immigrants in Mexico. Oakland: University of California Press.

Gudmundson, Lowell, 1986. Costa Rica Before Coffee: Society and Economy on the Eve of the Export Boom. Baton Rouge: Louisiana State University Press.

Harpelle, Ronald N., 2001. The West Indians of Costa Rica: Race, Class, and the Integration of an Ethnic Minority. Montreal QC: McGill-Queens University Press.

Hsu, Madeline Y., 20oo. Dreaming of Gold, Dreaming of Home: Transnationalism and Migration Between the United States and South China, 1882-1943. Stanford CA: Stanford University Press.

Hu-DeHart, Evelyn, 198o. Immigrants to a Developing Society: The Chinese in Northern Mexico, 1875-1932. Journal of Arizona History 21(3):275-312.

Hu-DeHart, Evelyn, 1982. Racism and Anti-Chinese Persecution in Mexico. Amerasia Journal 9(2):1-28.

Hu-DeHart, Evelyn, 1989. Coolies, Shopkeepers, Pioneers: The Chinese of Mexico and Peru (1849-1930). Amerasia Journal 15(2):91-116.

Hu-DeHart, Evelyn, 2002. Huagong and Huashang: The Chinese as Laborers and Merchants in Latin America and the Caribbean. Amerasia Journal 28(2):64-9o.

Hu-DeHart, Evelyn, 20o9. Indispensable Enemy or Convenient Scapegoat? A Critical Examination of Sinophobia in Latin America and the Caribbean, 1870s to 1930s. Journal of Chinese Overseas 5(1):55-90.

Huesman, James L., 1991. The Chinese in Costa Rica, 1855-1897. The Historian 53(4):71120. 
Instituto Confucio, 2016. Historias de la montaña de oro: Migraciones chinas a Costa Rica. Exposición documental, Sala de Exposiciones León Fernández Bonilla, Archivo Nacional de Costa Rica. http://institutoconfucio.ucr.ac.cr/sites/default/ files/IC_CATÁLOGO\%2016o\%2o.pdf.

Jung, Moon-Ho, 2006. Coolies and Cane: Race, Labor, and Sugar in the Age of Emancipation. Baltimore MD: Johns Hopkins University Press.

Kordick, Carmen, 2019. The Saints of Progress: A History of Coffee, Migration, and Costa Rican National Identity. Tuscaloosa: University of Alabama Press.

Kuhn, Philip A., 2008. Chinese Among Others: Emigration in Modern Times. Lanham MD: Rowman \& Littlefield Publishers.

Lee, Erika, 2003. At America's Gates: Chinese Immigration during the Exclusion Era, 18821943. Chapel Hill: University of North Carolina Press.

León Azofeifa, Moises Guillermo, 1987. Chinese Immigrants on the Atlantic Coast of Costa Rica: The Economic Adaptation of an Asian Minority in a Pluralistic Society. Ph.D. thesis, Tulane University, New Orleans.

Lohse, Russell, 2014. Africans into Creoles: Slavery, Ethnicity, and Identity in Colonial Costa Rica. Albuquerque: University of New Mexico Press.

López, Kathleen, 2013. Chinese Cubans: A Transnational History. Chapel Hill: University of North Carolina Press.

Loría Chaves, Marlene \& Alonso Rodríguez Chaves, 2001. La inmigración china a Costa Rica entre la explotación y la exclusion (1870-1910). Revista de Historia 44(2):159-92. McKeown, Adam, 2001. Chinese Migrant Networks and Cultural Change: Peru, Chicago, Hawaii, 1900-1936. Chicago: University of Chicago Press.

McKeown, Adam, 2008. Melancholy Order: Asian Migration and the Globalization of Borders. New York: Columbia University Press.

Meléndez, Carlos \& Quince Duncan, 1972. El Negro en Costa Rica. San José: Editorial Costa Rica.

Ossa, Luisa M. \& Debbie Lee-DiStifano (eds.), 2019. Afro-Asian Connections in Latin America and the Caribbean. Lanham MD: Lexington Books.

Palmer, Paula, 1993. "What Happen”: A Folk-History of Costa Rica's Talamanca Coast. San José: Publications in English, S.A. [Revised and expanded edition].

Palmer, Steven, 1996. Racismo intellectual en Costa Rica y Guatemala, 1870-1920. Mesoamérica 31:99-121.

Palmer, Steven, 199o. A Liberal Discipline: Inventing Nations in Guatemala and Costa Rica, 1870-1900. Ph.D. thesis, Columbia University, New York City.

Purcell, Trevor W., 1993. Banana Fallout: Class, Color, and Culture among West Indians in Costa Rica. Los Angeles: Center for Afro-American Studies Publications, University of California.

Putnam, Lara, 2002. The Company They Kept: Migrants and the Politics of Gender in Caribbean Costa Rica, 1870-1960. Chapel Hill: University of North Carolina Press. 
Putnam, Lara, 2006. Contact Zones: Heterogeneity and Boundaries in Caribbean Central America at the Start of the Twentieth Century. Iberoamericana 6(23):113-25.

Putnam, Lara, 2011. Undone by Desire: Migration, Sex across Boundaries, and Collective Destinies in the Greater Caribbean, 1840-1940. In Donna R. Gabbaccía \& Dirk Hoerder (eds.), Connecting Seas and Connected Ocean Rims: Indian, Atlantic, and Pacific Oceans and China Seas Migrations from the 1830 s to the 1930s. Leiden, the Netherlands: Brill, pp. 302-37. [Studies in Global History 8.]

Putnam, Lara, 2013. Radical Moves: Caribbean Migrants and the Politics of Race in the Jazz Ages. Chapel Hill: University of North Carolina Press.

Putnam, Lara, 2014. Migrants, Nations, and Empires in Transition: Native Claims in the Greater Caribbean, 185os-193os. In Nicola Foote \& Michael Goebel (eds.), Immigration and National Identities in Latin America. Gainesville: University Press of Florida, pp. 31-65.

Robinson, St. John, 2010. The Chinese of Central America: Diverse Beginnings, Common Achievements. In Walton Look Lai \& Chee-Beng Tan (eds.), The Chinese in Latin America and the Caribbean. Leiden, the Netherlands: Brill, pp. 103-28.

Romero, Robert Chao, 2010. The Chinese in Mexico, 1882-1940. Tucson: University of Arizona Press.

Schiavone Camacho, Julia María, 2012. Chinese Mexicans: Transpacific Migration and the Search for a Homeland, 1910-1960. Chapel Hill: University of North Carolina Press.

Siu, Lok C.D., 2005. Memories of a Future Home: Diasporic Citizenship of Chinese in Panama. Stanford CA: Stanford University Press.

Soto Quirós, Ronald, 2009. Percepciones y actitudes políticas con respecto a la minoría china en Costa Rica: 1897-1911. Historia y Espacio 32:165-223.

Young, Elliot, 2014. Alien Nation: Chinese Migration in the Americas from the Coolie Era through World War II. Chapel Hill: University of North Carolina Press.

Yun, Lisa, 2008. The Coolie Speaks: Chinese Indentured Laborers and African Slaves in Cuba. Philadelphia PA: Temple University Press. 